\title{
Connexin40 controls endothelial activation by dampening NFKB activation
}

\author{
Jean-Francois Denis ${ }^{1, *}$, K.E. Ludwig Scheckenbach ${ }^{1, *}$, Anna Pfenniger ${ }^{1,2}$, Merlijn \\ J. Meens ${ }^{1}$, Rob Krams ${ }^{3}$, Lucile Miquerol ${ }^{4}$, Steven Taffet ${ }^{5}$, Marc Chanson ${ }^{6}$, Mario \\ Delmar ${ }^{7}$ and Brenda R. Kwak ${ }^{1,2}$ \\ ${ }^{1}$ Department of Pathology and Immunology, University of Geneva, Geneva, Switzerland \\ ${ }^{2}$ Department of Medical Specializations - Cardiology, University of Geneva, Geneva, Switzerland \\ ${ }^{3}$ Department of Bioengineering, Imperial College, London, UK \\ ${ }^{4}$ Aix-Marseille University, CNRS UMR 7288, Developmental Biology Institute of Marseille, Marseille, France \\ ${ }^{5}$ Department of Microbiology, SUNY Upstate Medical University, Syracuse, NY, USA \\ ${ }^{6}$ Departments of Pediatrics and of Cell Physiology and Metabolism, Geneva University Hospitals and University of Geneva, \\ Geneva, Switzerland \\ ${ }^{7}$ The Leon H. Charney Division of Cardiology, New York University School of Medicine, New York, NY, USA \\ *These authors have contributed equally to this work \\ Correspondence to: Brenda R. Kwak, email: Brenda.KwakChanson@unige.ch \\ Keywords: atherosclerosis, endothelium, $\mathrm{Cx} 40$, shear stress, $1_{\kappa} \mathrm{B} \alpha$ \\ Received: November 08, $2016 \quad$ Accepted: February 27, $2017 \quad$ Published: March 22, 2017 \\ Copyright: Denis et al. This is an open-access article distributed under the terms of the Creative Commons Attribution License 3.0 \\ (CC BY 3.0), which permits unrestricted use, distribution, and reproduction in any medium, provided the original author and source \\ are credited.
}

\section{ABSTRACT}

Connexins are proteins forming gap junction channels for intercellular communication. Connexin40 ( $\mathrm{C} \times 40$ ) is highly expressed by endothelial cells (ECs) of healthy arteries but this expression is lost in ECs overlying atherosclerotic plaques. Low/oscillatory shear stress observed in bends and bifurcations of arteries is atherogenic partly through activation of the pro-inflammatory NFKB pathway in ECs. In this study, we investigated the relation between shear stress, Cx40 and NFKB. Shear stress-modifying casts were placed around carotid arteries of mice expressing eGFP

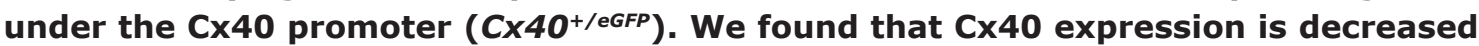
in carotid regions of oscillatory shear stress but conserved in high and low laminar shear stress regions. These results were confirmed in vitro. Using phage display, we retrieved a binding motif for the intracellular regulatory Cx40 C-terminus (Cx40CT), i.e. HS[I, L, V][K, R]. One of the retrieved peptides (HSLRPEWRMPGP) showed a $58.3 \%$ homology with amino acids 5-to-16 of $\mathrm{I} \kappa B \alpha$, a member of the protein complex inhibiting NFKB activation. Binding of IKB $\alpha$ (peptide) and Cx40 was confirmed by crosslinking and en face proximity ligation assay on carotid arteries. TNF $\alpha$-induced nuclear translocation of NFKB in ECs was enhanced after reducing Cx40 with siRNA. Transfection of HeLa cells with either full-length Cx40 or Cx40CT demonstrated that Cx40CT was sufficient for inhibition of TNF $\alpha$-induced NFKB phosphorylation. Finally, $\mathrm{Tie}^{2} \mathrm{Cre}^{T g} \mathrm{CX} 4 \mathrm{O}^{\pi / f} \mathrm{Apoe}^{-/-}$mice showed exaggerated shear stress-induced atherosclerosis and enhanced NFKB nuclear translocation. Our data show a novel functional $I_{\kappa} B \alpha-C \times 40$ interaction that may be relevant for the control of NFKB activation by shear stress in atherogenesis. 


\section{INTRODUCTION}

Atherosclerosis is a systemic lipid-driven inflammatory disease characterized by lesion formation in the intima of large and medium sized arteries. Rupture of atherosclerotic lesions is responsible for the majority of cardiovascular events such as myocardial infarction and stroke, which are the leading causes of death [1]. Atherosclerotic plaques display a variety of phenotypes: highly inflamed lesions with a large lipid pool and a thin fibrous cap are considered most vulnerable to rupture, whereas plaques with a high fibrous and smooth muscle cell content are generally recognized as more stable $[2,3]$. Despite the fact that the entire arterial tree is exposed to systemic risk factors such as hypertension, hypercholesterolemia and diabetes, atherosclerotic plaques typically develop at geometrically predisposed areas, like the lesser curvature of bended vessel segments or near arterial branch points; i.e. sites that are exposed to low and/or oscillatory blood flow [4-6].

Endothelial cells (ECs) lining the inner surface of blood vessels are constantly exposed to wall shear stress, the frictional drag force created by blood flow. ECs respond to changes in shear stress by modulating intracellular signaling, which ultimately leads to alterations in gene expression and cell morphology [5]. Low and/or oscillatory shear stress in athero-susceptible regions triggers a dysfunctional endothelial phenotype with expression of pro-inflammatory and pro-thrombotic mediators and an impaired endothelial barrier function $[4,5]$.

Pro-inflammatory activation of ECs involves activation of the NFkB signaling pathway [7]. The NFkB transcription factor is normally sequestered within the cytoplasm by its inhibitor I $\kappa$ B, which upon stimulation is phosphorylated by IKB kinase (IKK) and directed for proteasomal degradation, thereby releasing $\mathrm{NF} \kappa \mathrm{B}$ which subsequently translocates to the nucleus where it initiates gene transcription. Indeed, en face staining and microarray studies revealed higher expression of $\mathrm{NF \kappa B} / \mathrm{I} \kappa \mathrm{B}$ pathway components in ECs exposed to disturbed flow. However, $\mathrm{NF \kappa B}$ appeared only activated in a minority of the ECs and no significant differences were observed in expression of key adhesion molecules $[8,9]$. This suggests that NFkB signal transduction is already primed for activation in disturbed flow regions of arteries on encountering an activation stimulus [10]. Using shear stress-modifying casts on mouse carotid arteries, Cuhlmann and colleagues demonstrated induction of NFKB activation and enhanced vascular adhesion molecule-1 (VCAM-1) expression at the low/ oscillatory shear region downstream of the cast compared to the upstream low shear site [11]. Thus, low non-oscillatory and low oscillatory shear forces may have differential effects on EC activation and vascular inflammation.

The presence of gap junctions between ECs allows for a synchronized endothelial response by enabling the passage of ions and small metabolites between cells in contact [12]. Gap junction channels are made of connexins
(Cx), a family of transmembrane proteins that consists of 21 members in human. Three connexins are expressed in arterial $\mathrm{ECs}$, i.e. $\mathrm{Cx} 37, \mathrm{Cx} 40$ and $\mathrm{Cx} 43$ [12]. As they each form channels with different electrical properties and permeability, it is believed that they each play a unique role in endothelial homeostasis. We have previously shown that $\mathrm{Cx} 40$-mediated gap junctional communication contributes to maintenance of a quiescent non-activated endothelium by propagating adenosine-evoked antiinflammatory signals between ECs [13]. Whether Cx40 participates to the formation of shear stress-induced communication compartments in the arterial endothelium, and thus to the functional separation of athero-prone and athero-protective regions, is however presently unknown.

\section{RESULTS}

\section{Effect of shear stress on in vivo and in vitro $\mathrm{Cx} 40$ expression}

To investigate possible effects of shear stress on endothelial Cx40 expression, we first performed en face immunofluorescence on straight parts of the abdominal aorta and on the iliac bifurcation of $C x 40^{+/ e G F P}$ mice that express eGFP controlled by the $\mathrm{Cx} 40$ promoter. Whereas eGFP was highly present in the straight portions of the aorta that are exposed to physiological high laminar shear stress (HLSS), it was considerably reduced at the level of the iliac bifurcation, where an oscillatory shear stress (OSS) is anticipated (Figure 1A). Remarkably, the expression of eGFP varied considerably in the iliac bifurcation region and it was also not uniform in the abdominal aorta where cells expressing high levels of eGFP could be found adjacent to cells with a much lower eGFP expression. Then, shear stress-modifying casts were placed around the right common carotid artery of $C x 40^{+/ e G F P}$ mice as previously published $[14,15]$. First, Cx40 expression was determined in the casted and in the contralateral control carotids by en face immunofluorescence at 1 week after cast placement. As shown in Figure 1B, Cx40 was highly expressed in undisturbed control carotid arteries. Whereas this high expression was maintained in the laminar shear stress regions located inside the cast (HLSS) and upstream of the cast (low laminar shear stress; LLSS), Cx40 was decreased in the OSS region downstream of the cast. Quantification of immunosignal for $\mathrm{Cx} 40$ in 8 mice showed a reduction to more than half in the region subjected to OSS (Figure 1C). These results were confirmed by analyses of the eGFP signal in casted $C x 40^{+/ \ell G F P}$ mice (Figure 1D). Moreover, visualization of the eGFP signal in casted carotids showed a similar non-uniformity in expression levels of adjacent cells as observed at the level of the abdominal aorta. To exclude influence of systemic factors and circulating cells, flowdependent $\mathrm{Cx} 40$ regulation was also investigated in vitro. The mouse EC line bEnd.3 that constitutively expresses all vascular connexins [16] and is known to respond to changes in shear stress [15], was exposed to HLSS (20 

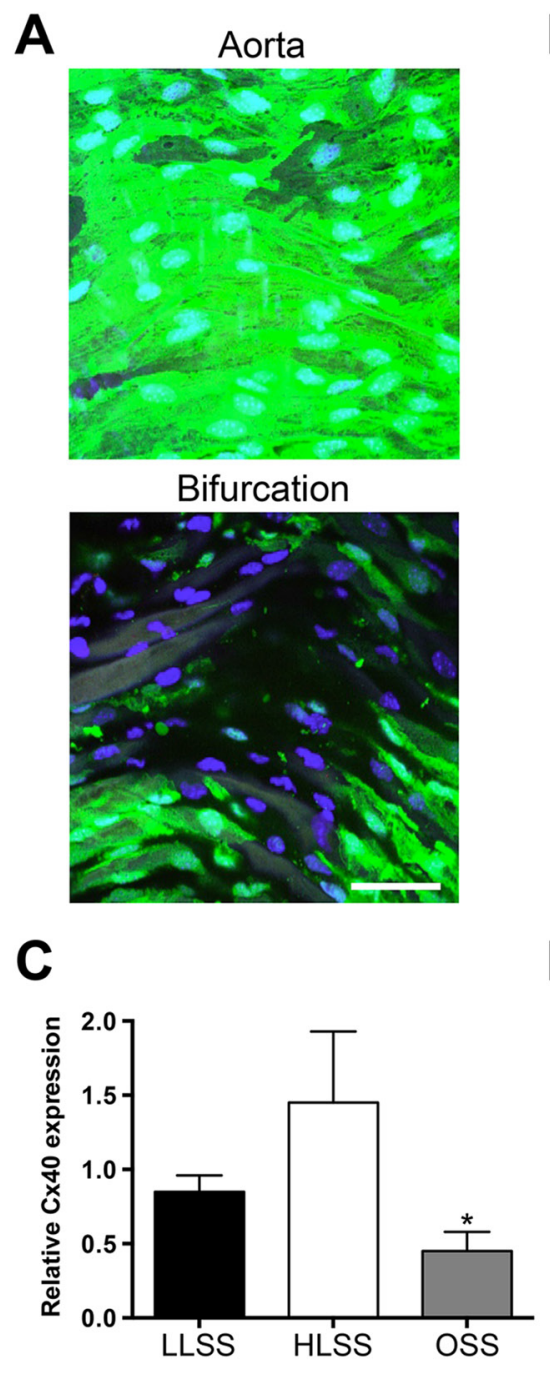

$\mathbf{E}$

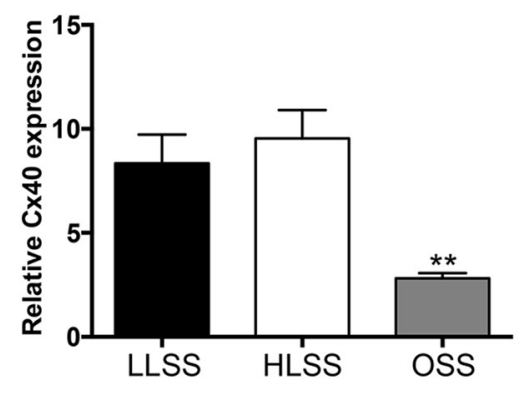

B

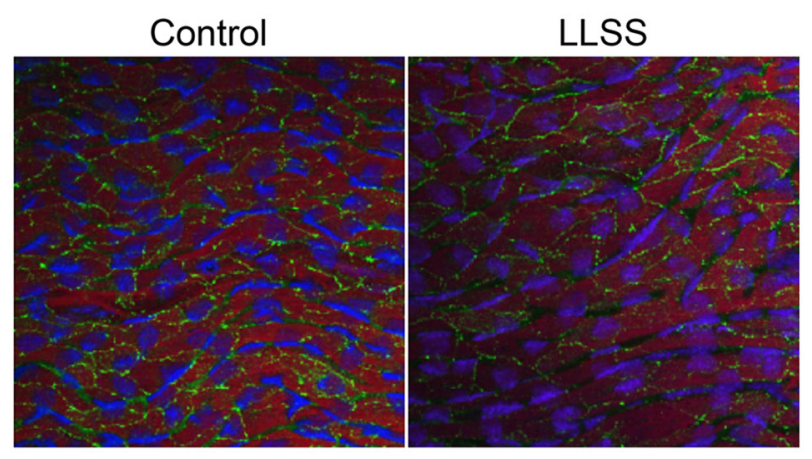

HLSS

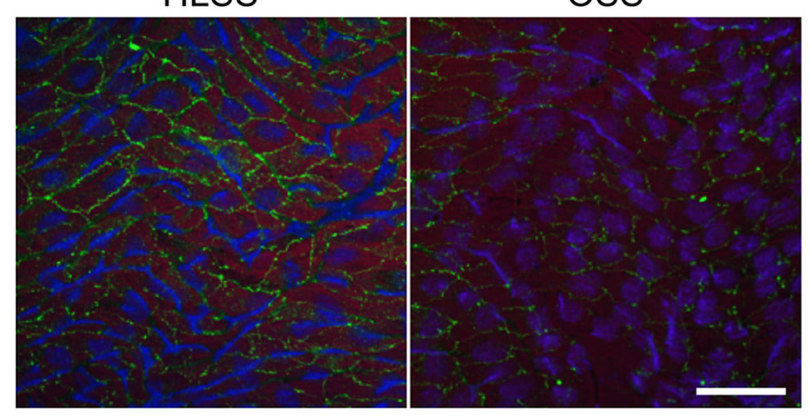

D

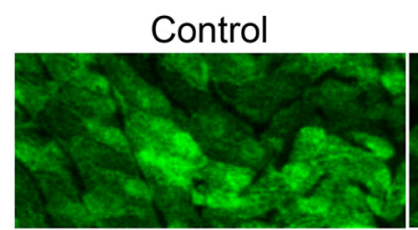

HLSS

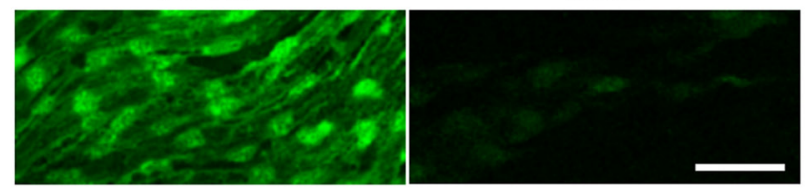

$\mathbf{F}$

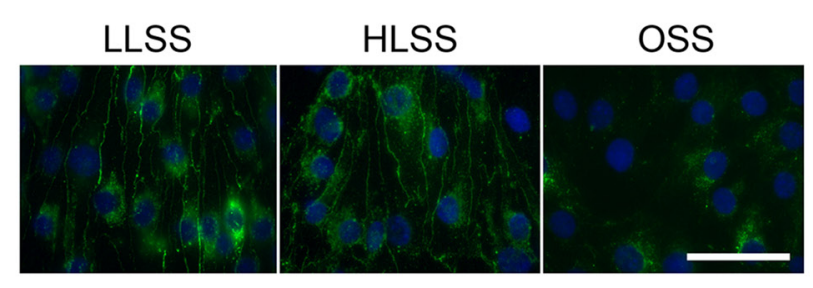

Figure 1: Expression of Cx40 is regulated by shear stress. (A) Representative en face images of eGFP in longitudinally opened carotids of $C x 40^{+/ e G F P}$ mice. eGFP (green) is highly expressed in the straight portions of the vessel (upper panel) but not at the iliac bifurcation (lower panel). DAPI (blue). (B) $\mathrm{Cx} 40$ expression (green) after modification of shear stress by a vascular cast in $C \times 40^{+/ e G F P}$ mice. Shown are the contralateral undisturbed vessel (control) and the regions upstream (LLSS), within (HLSS) and downstream of the cast (OSS). Evans Blue (red). DAPI (blue). (C) Quantification of (B); N=8. (D) eGFP after modification of shear stress by a vascular cast in $C x 40^{+/ / G F P}$ mice. Shown are the contralateral undisturbed vessel (control) and the regions upstream (LLSS), within (HLSS) and downstream of the cast (OSS). (E) Cx40 expression in bEnd. 3 cells exposed to static, HLSS, LLSS, OSS conditions for 24 hours was assessed by realtime qPCR. N=5. (F) Representative images of $\mathrm{Cx} 40$ expression (green) in bEnd.3 cells exposed to HLSS, LLSS, OSS for 24 hours. Scale bar represents $50 \mu \mathrm{m}$ for in (A), (B) and (D), and $40 \mu \mathrm{m}$ in (F). 
dynes $/ \mathrm{cm}^{2}$ ), LLSS (5 dynes/cm²) or OSS (5 dynes/cm²; $1 \mathrm{~Hz}$ ) for 24 hours or kept under static conditions. Again, OSS reduced $\mathrm{Cx} 40$ transcripts and protein when compared to HLSS as well as LLSS, as shown by quantitative PCR (qPCR) and immunofluorescence, respectively (Figure 1E and $1 \mathrm{~F}$ ). Thus, $\mathrm{Cx} 40$ expression in ECs is modulated by blood flow, being decreased in regions exposed to OSS.

\section{Phage display to identify potential binding partners}

Cx40 is traditionally considered a gap junction protein essential for direct cell-to-cell communication in the vasculature [12]. However, recently increasing attention is given to channel-independent functions of connexins [17, 18]. Therefore, we carried out a highthroughput phage display screening in search of peptidic sequences that bind to the intracellular C-terminus of Cx40 (Cx40CT). We analyzed the sequence of the insert retrieved from a total of 118 plaques. Of the estimated $2.5 \times 10^{9}$ different sequences presented in the phage display, 22 were captured by recombinant $\mathrm{Cx} 40 \mathrm{CT}$. Table 1 shows the corresponding peptide sequences and the number of plaques analyzed that contained the same sequence. When compared to the pre-bound library, basic residues were more frequently found in the captured peptides, whereas acidic residues showed minimal differences (Table 2). Strikingly, half of the captured peptide sequences presented amino acids $\mathrm{HS}[\mathrm{I}, \mathrm{L}, \mathrm{V}][\mathrm{K}, \mathrm{R}]$ as part of their sequence (Table 1). We calculated the probability of occurrence of this motif by chance alone taking into account the abundance of individual amino acids in the library prior to screening. The actual occurrence of this specific sequence appeared more than 300 times higher than its expected probability (Table 3 ). As Cx43CT and Cx37CT are known for their preferential capture of RXP and RXXP motifs, we also calculated the actual occurrence for these motifs in our Cx40CT phage display. We found a slight (1.8 times) increased occurrence of the RXP motif whereas the RXXP motif was even less frequently encountered than its expected probability (Table 3 ). Altogether, the data support the notion that $\mathrm{Cx} 40 \mathrm{CT}$ binds with enhanced selectivity to peptides containing the motif $\mathrm{HS}[\mathrm{I}, \mathrm{L}, \mathrm{V}][\mathrm{K}, \mathrm{R}]$.

Subsequent sequence alignments using the Basic Local Alignment Search Tool (BLAST) against the National Center for Biotechnology Information protein database indicated homology between two of the retrieved sequences and the N-terminus (NT) of I $\mathrm{B} \alpha$, a member of the protein family that inhibits the nuclear translocation of $\mathrm{NF \kappa B}$. The most frequently retrieved I $\mathrm{IB} \alpha$-like sequence (i.e. HSLRPEWRMPGP indicated with an asterisk in Table 1) contained the HS[I, L, V][K, R] motif and showed a 58.3\% homology with amino acids 5 to 16 of $\mathrm{I} \kappa \mathrm{B} \alpha$. Given the biological importance of NFKB translocation in arterial ECs in regions exposed to OSS and the specific decrease of $\mathrm{Cx} 40$ in this region, we continued with further characterization of interactions between this peptide and $\mathrm{Cx} 40 \mathrm{CT}$.

\section{In vitro and in situ binding of $\mathrm{Cx} 40$ and IкBa}

We used cross-linking experiments with $\mathrm{BS}^{3}$ to confirm the intermolecular interaction between $\mathrm{Cx} 40 \mathrm{CT}$ and the peptide showing the highest homology to I $\kappa \mathrm{B} \alpha$ (called: "I $\mathrm{BB} \alpha$-like") as well as a 12-mer peptide corresponding to sequence $5-16$ of $\mathrm{I} \kappa \mathrm{B} \alpha$ (called: "I $\mathrm{KB} \alpha(5-16)$ )"). As indicated by the arrow in Figure $2 \mathrm{~A}$, a band at $\sim 16-17 \mathrm{kDa}$ representing Cx40CT was seen in all samples, however in the first and the third lane, where samples contained I $\kappa \mathrm{B} \alpha(5$ 16) or I $\mathrm{K} \mathrm{B} \alpha$-like peptides respectively, a supplementary band, corresponding to the Cx40CT-peptide complex, was seen just above the Cx40CT band (as indicated by the arrowhead). Control experiments in the absence of peptides (Figure 2A, lane 2) or in the absence of $\mathrm{BS}^{3}$ (not shown) did not reveal this supplementary band. We further investigated the potential interaction between $\mathrm{Cx} 40$ and $\mathrm{I} \kappa \mathrm{B} \alpha$ using in situ proximity ligation assays (PLA). This method employs proximity probes - oligonucleotides attached to secondary antibodies - to guide formation of circular DNA strands when bound in close proximity $(\sim 30$ $\mathrm{nm})$. The DNA circles subsequently serve as templates for localized rolling-circle amplification, allowing visualization of protein-protein interactions [19]. As shown in Figure 2B (left panel), $\mathrm{Cx} 40$ and I $\mathrm{B} \alpha \alpha$ were detected in close proximity in carotid endothelium (red signal) most frequently as an intracellular signal but sometimes also at cell-cell interfaces that were highlighted by a green $\mathrm{Cx} 37$ immunosignal. No (red) signal was detected in negative controls from which the antibody detecting $\mathrm{I} \kappa \mathrm{B} \alpha$ was omitted (Figure $2 \mathrm{~B}$, right panel). Altogether, these data show that $\mathrm{Cx} 40$ and $\mathrm{I} \kappa \mathrm{B} \alpha$ are interacting proteins and that this interaction is most apparent in the intracellular compartment.

\section{Functional effect of $\mathrm{Cx} 40-\mathrm{I} \kappa \mathrm{B} \alpha$ interaction}

To study possible functional effects of the interaction between $\mathrm{Cx} 40$ and $\mathrm{I} \kappa \mathrm{B} \alpha$, we used bEnd. 3 cells stimulated with $10 \mathrm{ng} / \mathrm{ml} \mathrm{TNF} \alpha$ for various periods (0-60 min). As shown in Figure 3A and 3B, expression levels of $\mathrm{Cx} 40$ and $\mathrm{NF} \kappa \mathrm{B}$ were not affected by $\mathrm{TNF} \alpha$ stimulation for periods up to $60 \mathrm{~min}$. Stimulating bEnd. 3 cells for $10 \mathrm{~min}$ with TNF $\alpha$ induced I $\kappa \mathrm{B} \alpha$ phosphorylation at positions 32 and 36 (Figure $3 \mathrm{~A})$, an event that is known to precede phosphorylation of $\mathrm{NF \kappa B}$ and its subsequent translocation to the nucleus [7]. As expected, phosphorylation of I $\mathrm{IB} \alpha$ was accompanied by a concomitant degradation of the protein, visible in the Western blot as a decreased signal at 10 and $15 \mathrm{~min}$ (Figure $3 \mathrm{~A})$, after which the protein was re-expressed at $60 \mathrm{~min}$. Phosphorylation of I $\kappa \mathrm{B} \alpha$ was increased by 8 -fold and the $\mathrm{I} \kappa \mathrm{B} \alpha$ protein was reduced by half after stimulating bEnd. 3 cells for 15 min with TNF $\alpha$ (Figure 3B).

Next, we exposed bEnd. 3 cells to Cx40 siRNA and studied NF $\kappa$ B translocation by immunofluorescence. $\mathrm{Cx} 40$ expression was virtually absent after exposure to $25 \mathrm{nM}$ Cx40 siRNA, whereas the same concentration of nontargeting siRNA (NT siRNA) did not affect its expression, 
Table 1: Alignments of peptidic sequences derived from the phage display screen

\begin{tabular}{|c|c|}
\hline 15 & 5'-HSLRPEWRMPGP-3' * \\
\hline 1 & 5'-TMHSLRPEWRMP-3' \\
\hline 2 & 5'-HSLKPSWLLLGY-3' \\
\hline 1 & 5'-HSVKPDWAQMLR-3' \\
\hline 34 & 5'-HSVKPVVNLILR-3' \\
\hline 2 & 5'-HSLKPSLKQLAI-3' \\
\hline 10 & 5'-HSIRTYWQSAQP-3' \\
\hline 2 & 5'-HSLREDWTLRMQ-3' \\
\hline 1 & 5'-HSVKHDFRLLTK-3' \\
\hline 19 & 5'-HSIRLHTYPHMK-3' \\
\hline 1 & 5'-HSIRSSHLHMFT-3' \\
\hline 18 & 5'-YSLRADSRWMPS-3' \\
\hline 1 & 5'-SGHQL-LLNKMPN-3' \\
\hline 1 & 5'-APRLPQSLLPQL-3' \\
\hline 1 & 5'-SHALPLTWSTAA-3' \\
\hline 2 & 5'-APPGNWRNYLMP-3' \\
\hline 1 & 5'-APPMSRQSFDGV-3' \\
\hline 1 & 5'-NFMESLPRLGMH-3' \\
\hline 1 & 5'-LLADTTH-HRPWT-3' \\
\hline 1 & 5'-MEGQYKSNLLFT-3' \\
\hline 1 & 5'-NTELTSYGPPPA-3' \\
\hline 2 & 5'-TMGFTAPRFPHY-3' \\
\hline
\end{tabular}

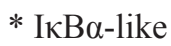

Red: HS[I, L, V][K, R] motif; Blue: [K, R]XP motif; Green: [K, R]XXP motif

Numbers represent occurrence of the peptidic sequence in the phage display.

Table 2: Frequency of acidic and basic residues in phage display sequences

\begin{tabular}{lcc}
\hline & Cx40 display & library \\
\hline Asp & $2.3 \%$ & $2.8 \%$ \\
Glu & $2.3 \%$ & $3.1 \%$ \\
His & $8.3 \%$ & $6.3 \%$ \\
Lys & $3.8 \%$ & $2.8 \%$ \\
Arg & $7.2 \%$ & $4.7 \%$ \\
\hline
\end{tabular}

Table 3: Frequency of HS[I, L, V], [K, R] or [K, R]XP or [K, R]XXP motifs in the Cx40CT phage display versus theoretical occurrence

\begin{tabular}{lccc}
\hline & $\mathbf{H S}[\mathbf{I}, \mathbf{L}, \mathbf{V}],[\mathbf{K}, \mathbf{R}]$ & {$[\mathbf{K}, \mathbf{R}] \mathbf{X P}$} & {$[\mathbf{K}, \mathbf{R}] \mathbf{X X P}$} \\
\hline Theoretical frequency & $0.157 \%$ & $12.54 \%$ & $11.3 \%$ \\
Experimental frequency & $50.0 \%$ & $22.7 \%$ & $4.5 \%$ \\
Ratio Exp/Th & 318.9 & 1.8 & 0.4 \\
\hline
\end{tabular}



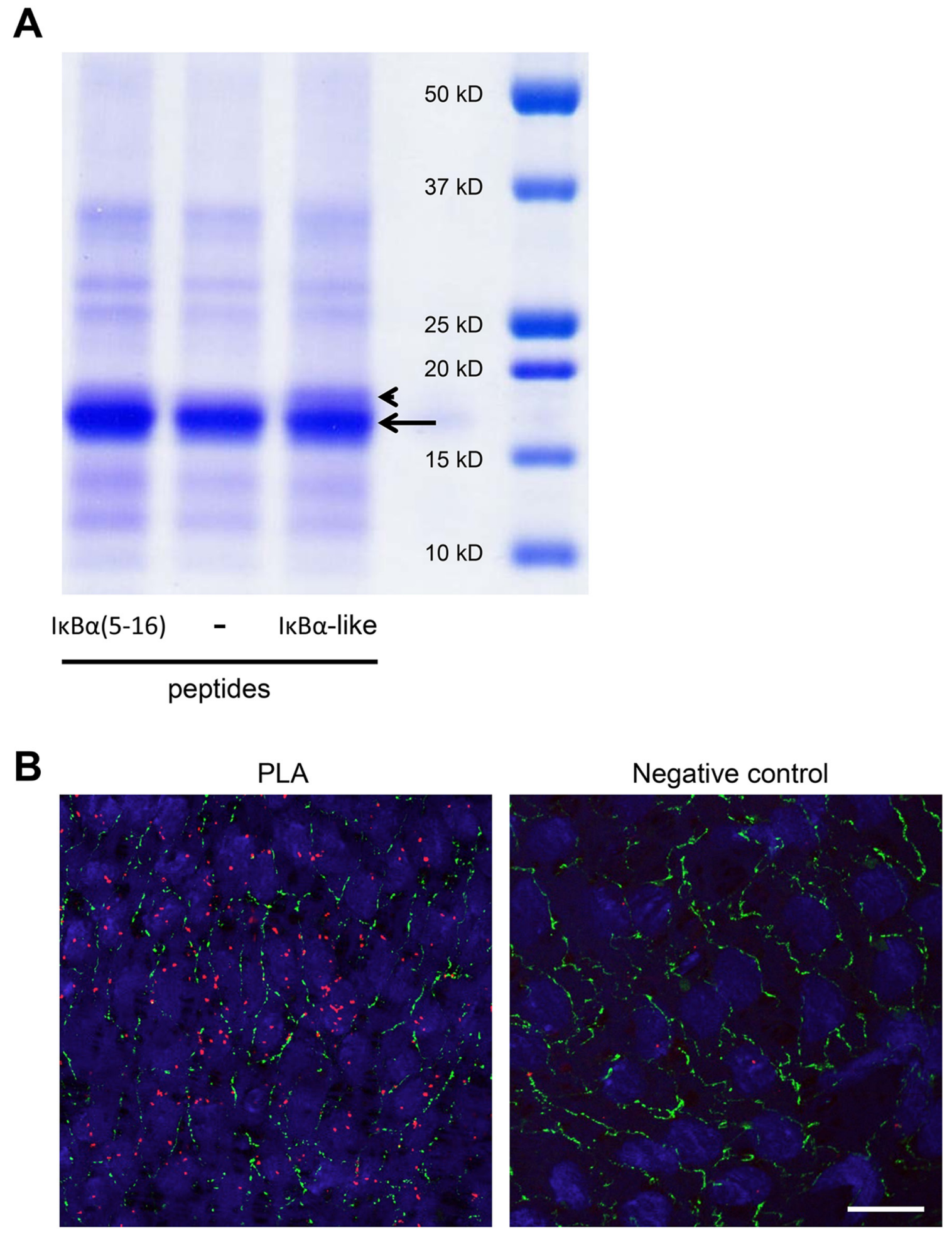

Figure 2: $\mathrm{Cx} 40$ and $\mathrm{I} \kappa \mathrm{B} \alpha$ interact in vitro and in vivo. (A) Cross-linking experiment with $\mathrm{Cx} 40 \mathrm{CT}$ and peptides. Binding of $\mathrm{I} \kappa \mathrm{B} \alpha-$ like or IкB $\alpha(5-16)$ peptides to $\mathrm{Cx} 40 \mathrm{CT}$ was assessed after incubation with the chemical cross-linker BS ${ }^{3}$. All lanes show a band at $\sim 16-17$ $\mathrm{kDa}$ representing Cx40CT (arrow). The first and third lanes of the panel show an additional band at $\sim 17-18 \mathrm{kDa}$ (arrow head), which is absent in lane 2, where the peptide is missing. (B) Representative en face images of PLA (out of 3 experiments) performed with antibodies

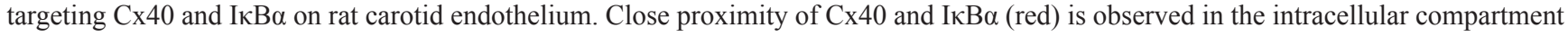
as well as at cell-cell contacts (left panel). Control assays revealed that the red staining observed was no longer observed after omitting either the $\mathrm{Cx} 40$ or the I $\mathrm{B} \alpha \alpha$ antibody from the PLA (right panel). Cx37 staining (green) is used to highlight the intercellular gap junctions. DAPI (blue). Scale bar represents $20 \mu \mathrm{m}$. 

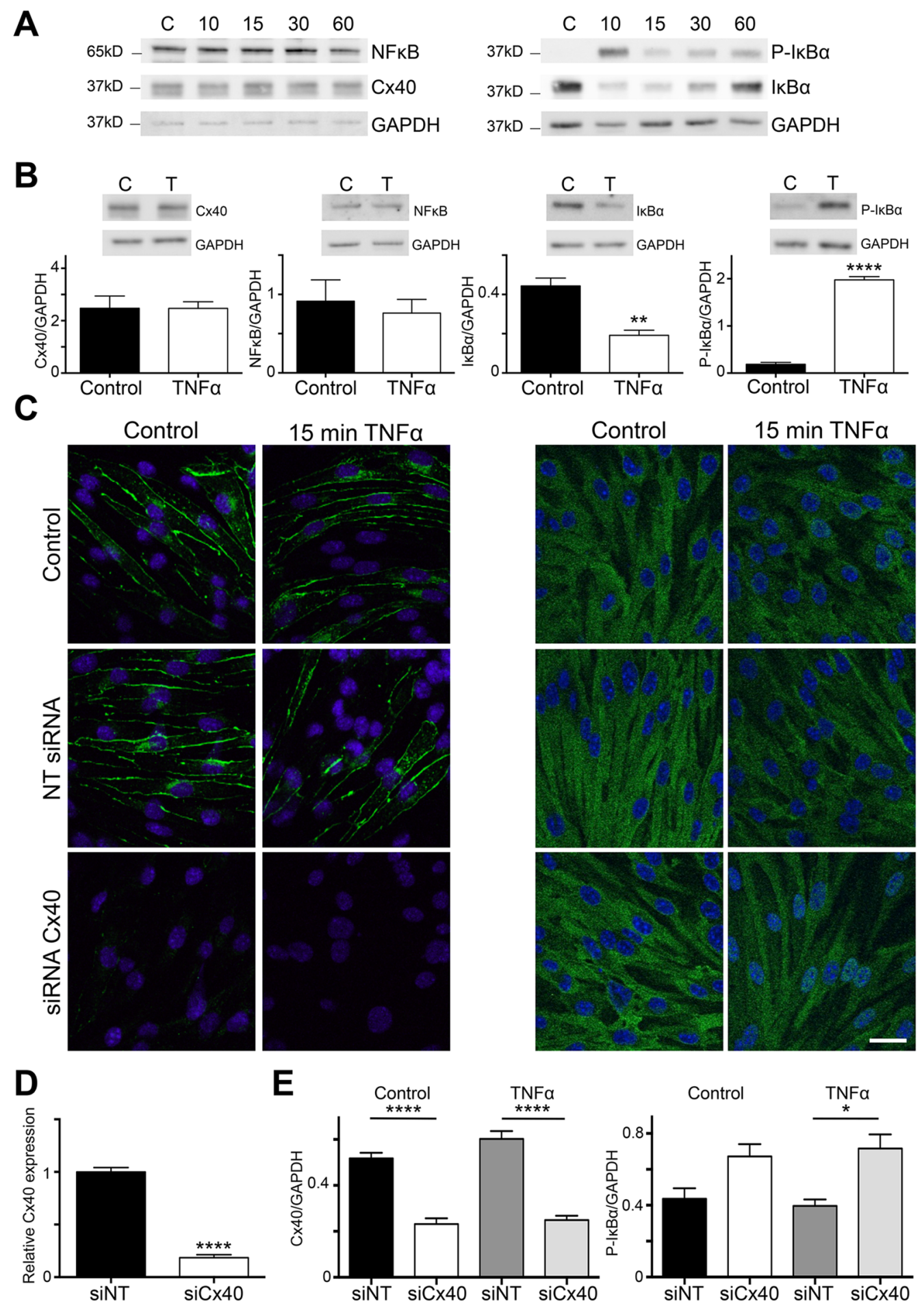

Figure 3: Cx40 dampens NFкB nuclear translocation in a mouse EC line. (A) Lysates of bEnd.3 cells incubated or not with

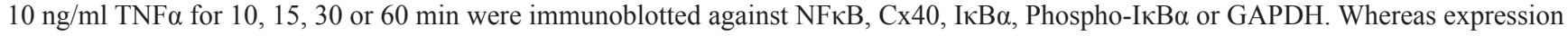
levels of $\mathrm{NF} \kappa \mathrm{B}, \mathrm{Cx} 40$, and GAPDH were not affected by short-term stimulation with TNF $\alpha$, the treatment induced phosphorylation and degradation of IKB $\alpha$. (B) Quantification of (A) under control conditions or after incubation with $10 \mathrm{ng} / \mathrm{ml} \mathrm{TNF} \alpha$ for $15 \mathrm{~min}$. N=3. (C) Expression of $\mathrm{Cx} 40$ (left panels) or NFKB (right panels; both in green) in control bEnd.3 cells and after $15 \mathrm{~min}$ stimulation with $10 \mathrm{ng} / \mathrm{ml}$ $\mathrm{TNF} \alpha$ treated or not with siRNA for Cx40 or NT-siRNA. Note that in ECs in which Cx40 was silenced with siRNA (lower panels), NFkB translocation to the nucleus was enhanced after stimulation with TNF $\alpha$. DAPI (blue). Scale bar represents $15 \mu \mathrm{m}$. (D) Cx40 expression in bEnd. 3 cells exposed to Cx40 siRNA or NT-siRNA was assessed by real-time qPCR. N=3. (E) Expression of Cx40 (left) or Phospho-IkB $\alpha$ (right) in control bEnd.3 cells and after $15 \mathrm{~min}$ stimulation with $10 \mathrm{ng} / \mathrm{ml} \mathrm{TNF} \alpha$ treated with siRNA for Cx40 or NT-siRNA. N=3. 
both under control conditions or after $15 \mathrm{~min} \mathrm{TNF} \alpha$ stimulation (Figures 3C, left panels, and 3D). Exposure to $\mathrm{TNF} \alpha$ did not induce $\mathrm{NF} \kappa \mathrm{B}$ translocation to the nucleus in control or NT siRNA-transfected bEnd.3 cells (Figure 3C, upper and middle right panels). Interestingly, substantial TNF $\alpha$-induced nuclear translocation of NFאB was observed in bEnd.3 cells after effective inhibition of Cx40 by siRNA (Figure 3C, bottom right panel). Moreover, we also observed a significant increase in I $\kappa \mathrm{B} \alpha$ phosphorylation after 15 min stimulation with TNF $\alpha$ in bEnd. 3 cells after effective inhibition of $\mathrm{Cx} 40$ by siRNA (Figure 3E). Overall, the data suggest that the interaction of $\mathrm{I} \kappa \mathrm{B} \alpha$ with $\mathrm{Cx} 40$ decreases its phosphorylation, thereby resulting in reduced nuclear translocation of $\mathrm{NF} \kappa \mathrm{B}$.

\section{Functional effect of the $\mathrm{Cx} 40-\mathrm{I} \kappa \mathrm{B} \alpha$ interaction}

To investigate whether the inhibitory effect of $\mathrm{Cx} 40$ on NFאB translocation in ECs could be generalized to other cell types, we used communication-deficient parental HeLa cells and HeLa cells stably transfected with Cx40. Immunofluorescence confirmed absence of $\mathrm{Cx} 40$ in the parental cells and showed a high level of $\mathrm{Cx} 40$ expression in stably transfected HeLa cells (Figure 4A). Moreover, microinjection of Lucifer Yellow in one Cx40-transfected cell resulted in its spread to $\sim 8$ neighboring cells. In contrast, no cell-to-cell coupling was observed between parental HeLa cells (Figure 4B). Finally, we detected the induction of Phospho-NFкB by $20 \mathrm{ng} / \mathrm{ml} \mathrm{TNF} \alpha$ in parental and stably Cx40-transfected HeLa cells (Figure 4C). Whereas 5 min TNF $\alpha$ exposure induced a 25 -fold increase in NF $\mathrm{B}$ phosphorylation in parental cells (Figure $4 \mathrm{C}$, black bar and dotted line), the induction of $\mathrm{NF} \kappa \mathrm{B}$ phosphorylation was only 3-fold in $\mathrm{Cx} 40$-transfected HeLa cells (Figure 4C, white bar).

To study whether the inhibitory effect of $\mathrm{Cx} 40$ on NFאB translocation was dependent on functional gap junction channels or could be ascribed to channelindependent effects, we transiently transfected communication-deficient HeLa cells using a pIRESeGFP plasmid containing full-length $\mathrm{Cx} 40$ or $\mathrm{Cx} 40 \mathrm{CT}$. As expected, immunostaining revealed full-length $\mathrm{Cx} 40$ at cell-cell interfaces, whereas Cx40CT was detected only intracellularly in transfected HeLa cells (Figure 4D). Expression of $\mathrm{Cx} 40$ or Cx40CT was confirmed by Western blotting and demonstrated no major differences in expression levels between both proteins (Figure 4E). Moreover, Lucifer Yellow microinjection in one transiently Cx40-transfected cell resulted in its spread to $\sim 4$ neighboring cells, whereas no cell-to-cell coupling was observed between HeLa cells transiently transfected with Cx40CT (Figure 4F). Finally, 5 min TNF $\alpha$ exposure induced about 12-fold increase in $\mathrm{NF} \kappa \mathrm{B}$ phosphorylation in both $\mathrm{Cx} 40$ or $\mathrm{Cx} 40 \mathrm{CT}$ transiently transfected HeLa cells (Figure 4G). Thus, the inhibitory effect of $\mathrm{Cx} 40$ on $\mathrm{NF} \kappa \mathrm{B}$ phosphorylation/activation is not restricted to ECs and is independent of functional gap junction channels.

\section{Exaggerated induction of atherosclerosis in EC- Cx40-deficient mice}

Whereas low shear stress levels prime ECs by increasing $\mathrm{NF} \kappa \mathrm{B}$ expression, OSS seems to induce arterial inflammation by promoting not only NFאB expression but also its nuclear localization in ECs [11]. To investigate the role of endothelial $\mathrm{Cx} 40$ in flow-induced atherosclerosis in vivo, we used atherosclerosis-susceptible mice in which Cx40 was deleted from the endothelium [13]. Shear stressmodifying casts were placed around the right common carotid artery and the mice were fed a high-cholesterol diet for 6 weeks. As shown previously for Apoe $^{-/}$mice $[14,20], C x 40^{A / f t} A_{p o e^{-/}}$controls showed intimal thickening in regions exposed to LLSS or OSS (Figure 5A). As expected, flow-induced atherosclerotic remodeling was significantly increased in Tie $2 \mathrm{Cre}^{T g} \mathrm{Cx} 40^{A / f} \mathrm{Apoe}^{-/-}$carotids (Figure $5 \mathrm{~B}$ and $5 \mathrm{C}$ ) with $0.97 \pm 0.01$ of the vessel surface being occluded in the LLSS region of Tie $2 \mathrm{Cre}^{T g} \mathrm{Cx} 40^{\mathrm{fl} /}$ ${ }^{A} A$ poe $^{-/}$carotids vs. only $0.54 \pm 0.06$ in carotids of $C x 40^{f /}$ ${ }^{A}{ }^{A p o e^{-/}}$mice. Of note, the increased atherosclerotic response resulted in complete occlusion of the LLSS area, which, in turn, gave rise to atherosclerotic lesions within the cast in half of the Tie2-cre ${ }^{T g} \mathrm{Cx} 40^{f / f} \mathrm{Apoe}^{-/-}$mice (see Figure 5C for an example). We further investigated the effect of endothelial deletion of $\mathrm{Cx} 40$ on the in situ location of $\mathrm{NF} \kappa \mathrm{B}$ by en face immunostaining for $\mathrm{NF} \kappa \mathrm{B}$ in longitudinally opened carotids of Tie $2 \mathrm{Cre}^{\mathrm{Tg}} \mathrm{Cx} 4 \mathrm{O}^{\mathrm{Al}}$ ${ }^{A} A$ poe $e^{-/}$and $C x 40^{f / f} A$ Apoe $e^{-/}$mice. As shown in Figure 5D, $\mathrm{NF} \kappa \mathrm{B}$ was detected mostly as a cytoplasmic signal in carotid arteries of $C x 40^{A / A} A p o e^{-/}$control mice. However, $\mathrm{NF} \kappa \mathrm{B}$ signal frequently co-localized with nuclei in carotids of Tie $2 \mathrm{Cre}^{\mathrm{Tg}} \mathrm{Cx} 4 \mathrm{O}^{\mathrm{Alf} / \mathrm{Ap}} \mathrm{Ape}^{-/-}$mice (Figure 5E). Overall, our study demonstrates that $\mathrm{Cx} 40$ and $\mathrm{I} \kappa \mathrm{B} \alpha$ are interacting proteins. Moreover, absence of $\mathrm{Cx} 40$ from the endothelium enhances NFkB nuclear translocation and exaggerates induction of atherosclerosis both in regions of OSS and LLSS.

\section{DISCUSSION}

During early atherogenesis, leukocytes are recruited to the arterial intima through secretion of chemokines and expression of adhesion molecules such as VCAM1, intercellular adhesion molecule-1 (ICAM-1) and P-selectin by activated ECs. A key regulator of these pro-inflammatory processes is the transcription factor

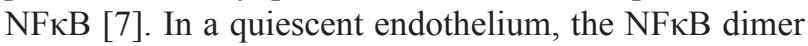
is kept in an inactive conformation through binding to the inhibitory I $\mathrm{B}$ protein. A variety of pro-inflammatory signals, like TNF $\alpha$ or OSS, trigger the activation of the IKK complex resulting in the phosphorylation of $\mathrm{I} \kappa \mathrm{B} \alpha$ at amino acids 32 and 36. Subsequent proteosomal degradation of $\mathrm{I} \kappa \mathrm{B} \alpha$ releases the NF $\mathrm{B}$ dimer (mostly p50-RelA) for nuclear translocation and initiation of gene transcription. NFאB signaling is subjected to a number of 


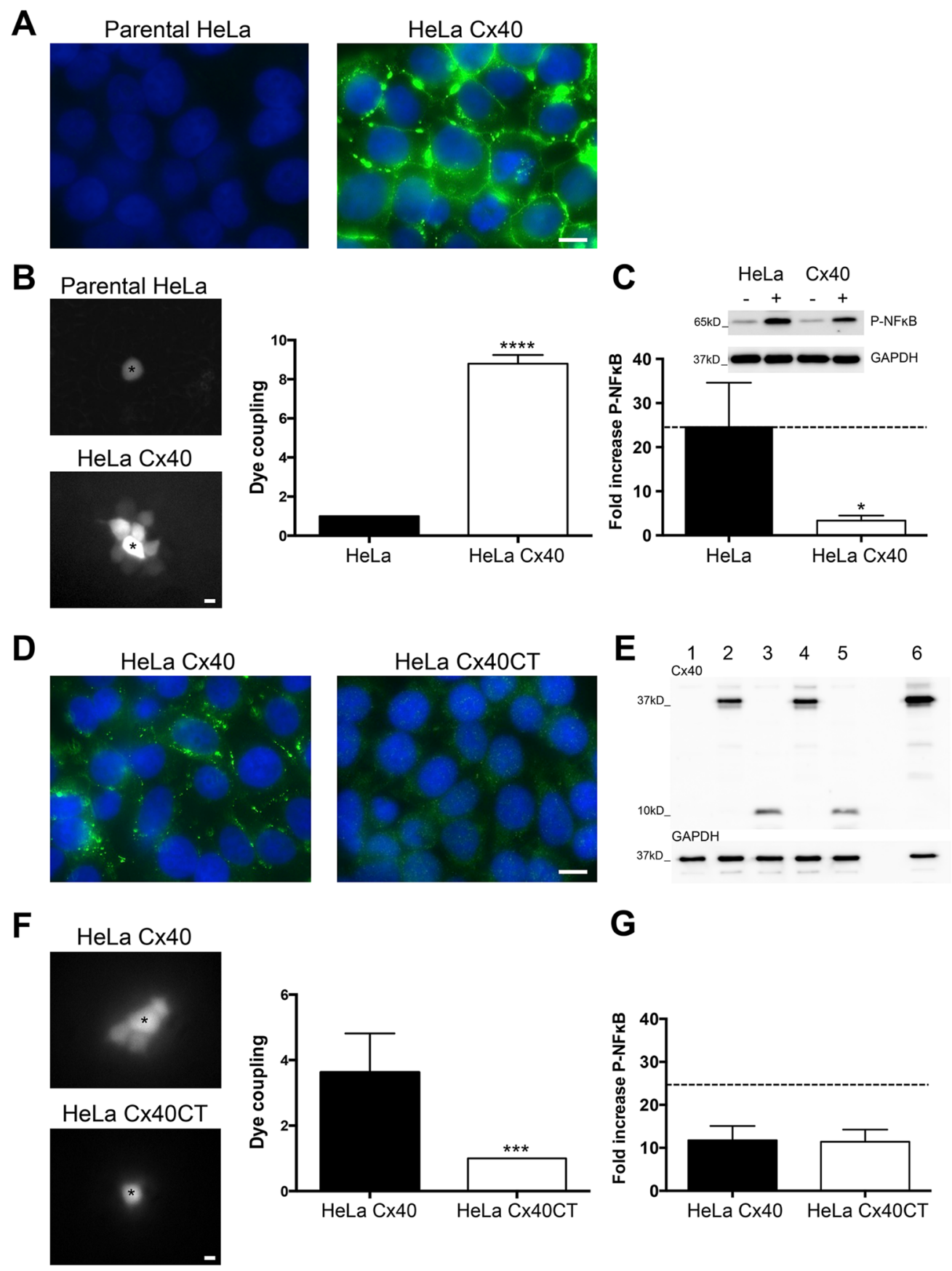

Figure 4: Cx40CT is sufficient for inhibition of TNF $\alpha$-induced NFkB activation. (A) Cx40 immunostaining (green) in communication-incompetent HeLa cells (left panel) and in HeLa cells stably transfected with Cx40 (right panel). DAPI (blue). (B) Intercellular communication was measured by Lucifer Yellow microinjection during $3 \mathrm{~min}$. Images are representative examples of Lucifer Yellow diffusion in parental HeLa cells (upper panel, $\mathrm{N}=6$ ) and in HeLa cells stably transfected with Cx40 (lower panel, N=10). Asterisks indicate the microinjected cells. (C) Western blots (upper panel) showing the induction of Phospho-NFkB after 5 min stimulation with 20 $\mathrm{ng} / \mathrm{ml} \mathrm{TNF} \alpha(+)$ as compared to control conditions (-) in parental HeLa cells and in HeLa cells stably transfected with Cx40. Expression of $\mathrm{Cx} 40$ reduced TNF $\alpha$-induced NFKB phosphorylation (lower panel). $\mathrm{N}=3$. (D) $\mathrm{Cx} 40$ immunostaining (green) in communication-incompetent HeLa cells transiently transfected with full-length $\mathrm{Cx} 40$ (left panel) or with $\mathrm{Cx} 40 \mathrm{CT}$ (right panel). DAPI (blue). (E) Lysates of parental HeLa cells (lane 1) or transiently transfected with Cx40 (lanes 2 and 4) or Cx40CT (lanes 3 and 5) or stably transfected with Cx40 (lane 6) were immunoblotted against $\mathrm{Cx} 40$ and GAPDH. (F) Intercellular communication was measured by Lucifer Yellow microinjection during 5 min. Images are representative examples of Lucifer Yellow diffusion in HeLa cells transiently transfected with $\mathrm{Cx} 40$ (upper panel, $\mathrm{N}=8$ ) or $\mathrm{Cx} 40 \mathrm{CT}$ (lower panel, $\mathrm{N}=6$ ). Asterisks indicate the microinjected cells. (G) Induction of Phospho-NFkB after 5 min stimulation with 20 ng/ $\mathrm{ml} \mathrm{TNF} \alpha$ in HeLa cells transiently transfected with $\mathrm{Cx} 40$ or $\mathrm{Cx} 40 \mathrm{CT}$. Expression of $\mathrm{Cx} 40$ or $\mathrm{Cx} 40 \mathrm{CT}$ revealed a similar protection against $\mathrm{TNF} \alpha$-induced $\mathrm{NF \kappa B}$ phosphorylation. $\mathrm{N}=3$. Scale bar represents $10 \mu \mathrm{m}$ in (A) and (D), and $15 \mu \mathrm{m}$ in (B) and (F). 


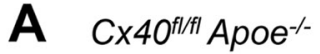

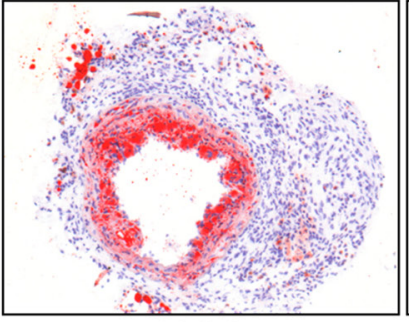

LLSS

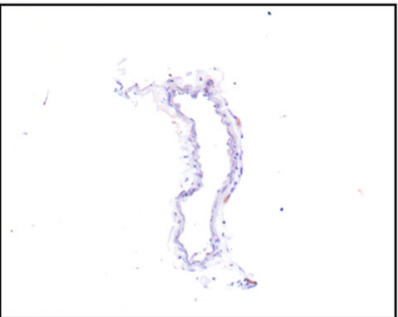

HLSS

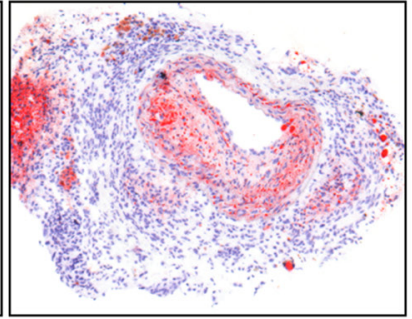

OSS

B Tie2-cre ${ }^{T g} \mathrm{C} \times 4 \mathrm{O}^{f / f / t} \mathrm{Apoe}^{-/}$

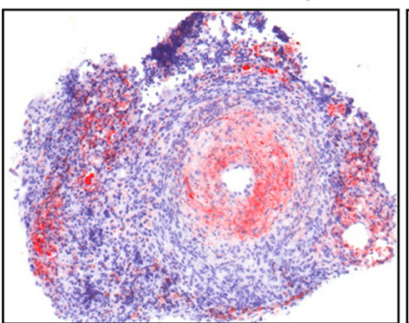

LLSS

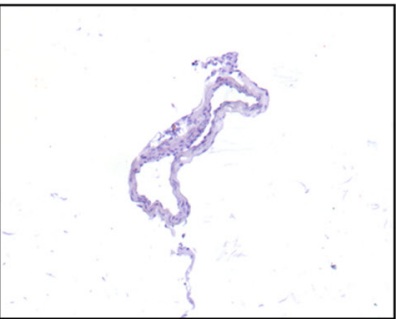

HLSS

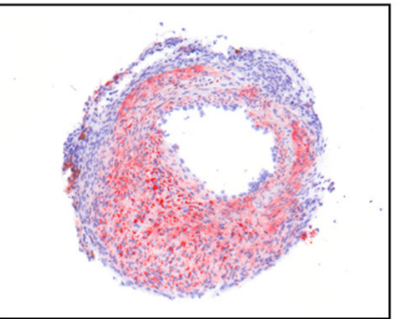

OSS

C Tie2-cre ${ }^{T g} \mathrm{Cx} 4 \mathrm{O}^{\mathrm{fl/fl}} \mathrm{Apoe}^{-/}$

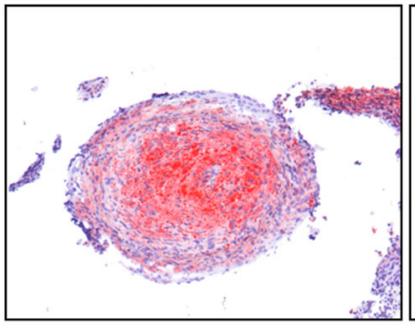

LLSS

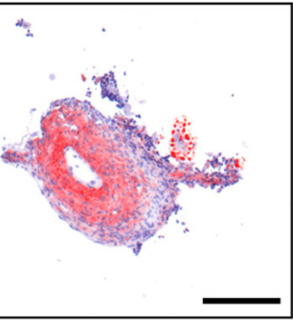

within cast

D $\mathrm{C} \times 40^{f / / f l} \mathrm{Apoe}^{-/}$
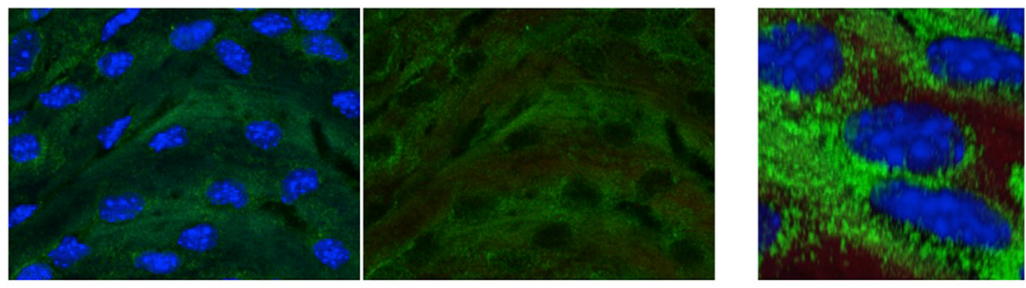

E

Tie2-cre ${ }^{T g} \mathrm{CX} 4 \mathrm{O}^{\mathrm{flfl}} \mathrm{Apo \textrm {A } ^ { - / - }}$
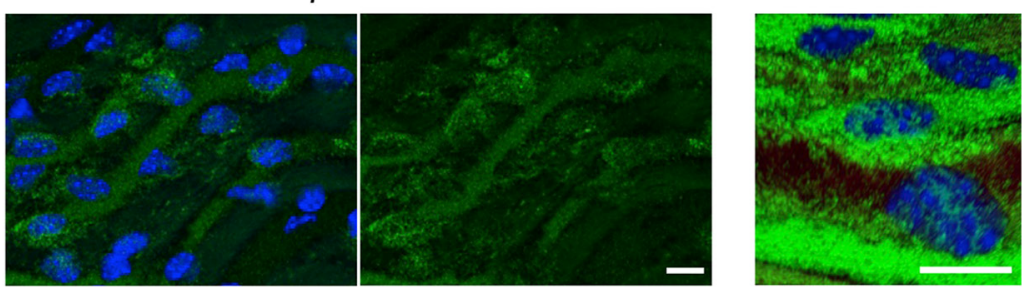

Figure 5: Exaggerated flow-induced atherosclerosis in $A_{p o e^{-}}$mice with endothelial deletion of Cx40. Representative images of SudanIV stainings are shown for the 3 flow regions of casted vessels (LLSS, HLSS, OSS) from Cx40 ${ }^{\sharp t / A} A p o e^{-\digamma}$ (A) and Tie2$\mathrm{cre}^{T_{g}} \mathrm{Cx} 40^{t / f} \mathrm{Apoe} \mathrm{e}^{-/}(\mathbf{B}, \mathbf{C})$ mice after 6 weeks of high-cholesterol diet. Intimal thickening was present in regions subjected to LLSS and OSS in $C x 40^{A / f} A p o e^{-/-}$mice (A). Intimal thickening in response to LLSS and OSS was increased in Tie2-cre ${ }^{T_{S}} C x 40^{A / f} A p o e^{-/}$mice (B). The increased atherosclerotic response caused in half of the Tie2-cre ${ }^{T g} \mathrm{Cx} 40^{A f / A} A p o e^{-/}$mice a complete occlusion of the LLSS area that gave rise to atherosclerotic lesions within the cast (C). N=6-8 animals per group. Scale bar $=200 \mu \mathrm{m}$. (D, E) En face immunostaining for NFKB

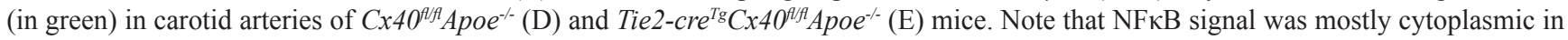

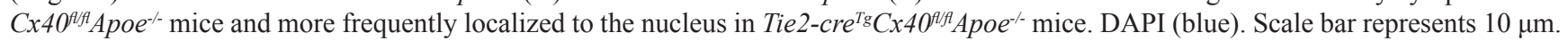


regulatory mechanisms, e.g. at the level of its inhibitor $\mathrm{I} \kappa \mathrm{B} \alpha$. Importantly, $\mathrm{NF} \kappa \mathrm{B}$ activation rapidly induces $\mathrm{I} \kappa \mathrm{B} \alpha$ expression, thus providing an auto-regulatory negative feedback loop [21]. In addition, I $\mathrm{B} \alpha$ stability is controlled by the COP9 signalosome that regulates deneddylation and deubiquitination processes, even under $\mathrm{NF} \kappa \mathrm{B}$ activating conditions $[22,23]$. In this study, we add $\mathrm{Cx} 40$ to the collection of proteins that critically regulate endothelial NF $\kappa \mathrm{B}$ signaling.

ECs display a large degree of heterogeneity. I.e. ECs at athero-prone sites express relatively high levels of NFkB, whereas ECs at athero-protected sites express low amounts of $\mathrm{NF \kappa B}$ proteins and are resistant to activation [10]. This spatial difference in EC behavior has been attributed to spatial variation in hemodynamic forces: athero-protected sites are exposed to high rates of unidirectional flow, while athero-susceptible sites experience lower rates of unidirectional or oscillatory flow [5]. Using shear stress-modifying casts, Cuhlmann and colleagues elegantly demonstrated that low shear may prime ECs for inflammatory activation by inducing NFאB expression, whereby oscillatory shear promoted both expression and nuclear localization (activation) of $\mathrm{NF \kappa B}$ [11]. The reason for this difference was not investigated. Here, we observed a reduction in $\mathrm{Cx} 40$ in response to OSS, whereas Cx40 expression was preserved at sites of LLSS. We further demonstrated that inhibition of Cx40 expression favors the translocation of $\mathrm{NF} \kappa \mathrm{B}$ in $\mathrm{ECs}$ in vitro (Figure 3C) as well as in situ (Figure 5D and 5E). Finally, the endothelium in aortic sinuses (a typical OSS location) of 10 weeks-old Tie2 $\mathrm{Cre}^{T g} \mathrm{Cx} 40^{A / / A} \mathrm{Apoe}^{-/-}$mice expresses the $\mathrm{NF} \kappa \mathrm{B}$-inducible protein VCAM-1 while this protein is absent at this location in young control mice [13]. Together, these results suggest that the presence of $\mathrm{Cx} 40$ in the endothelium of LLSS regions dampens NFאB activation despite increased expression levels in these regions.

Gap junction-mediated intercellular communication (GJIC) governed by Cx37, Cx40 and Cx43 between arterial ECs is important in vascular physiology as it synchronizes the response of ECs to various agonists [12]. For instance, GJIC assures a homogeneous increase in cytosolic calcium and subsequent activation of eNOS following exposure to histamine despite a focal expression pattern of the histamine receptor H1 in arterial ECs [24]. Moreover, connexins affect vascular pathology, including atherosclerosis. Whereas Cx43 plays an atherogenic role $[25,26] \mathrm{Cx} 37$ and $\mathrm{Cx} 40$ are athero-protective $[13,27]$. Interestingly, the expression of the three connexins seems differently regulated by arterial shear stress patterns; Cx43 is abundantly expressed in aortic endothelia localized downstream of ostia of branching vessels and at flow dividers [28]. Moreover, HLSS enhances Cx37 expression in carotid ECs by inducing its transcription factor KLF2, which increases GJIC and contributes to EC synchronization [15]. In contrast to $\mathrm{Cx} 40, \mathrm{Cx} 37$ expression is decreased in OSS as well as LLSS regions [15]. Finally, shear stress-dependent endothelial Cx40 expression in small arteries and arterioles plays an important role in signal propagation along blood vessel walls, thereby modulating vessel diameter and organ blood flow [29]. Using a mouse model expressing eGFP under the control of the $\mathrm{Cx} 40$ promoter, our study reveals for the first time heterogenous $\mathrm{Cx} 40$ promoter activity in ECs of large arteries, which is most pronounced in areas of LLSS but also present in HLSS regions. This nonuniform $\mathrm{Cx} 40$ expression in adjacent ECs led us to search for GJIC-independent functions of $\mathrm{Cx} 40$ and this led to the identification of $\mathrm{I} \kappa \mathrm{B} \alpha$ as a new binding partner for the intracellular $\mathrm{Cx} 40 \mathrm{CT}$. The I $\mathrm{B} \alpha$-like peptide contains the HS[I, L, V][K, R] motif as part of its sequence. The occurrence of this specific motif in our Cx40CT phage display was more than 300 times higher than its expected probability. Moreover, this specific motif was not found in earlier phage displays for Cx43CT or Cx37CT [30, 31], suggesting that $\mathrm{I} \kappa \mathrm{B} \alpha$ may be an exclusive binding partner for Cx40 in ECs. Our subsequent transfection studies with full-length $\mathrm{Cx} 40$ and $\mathrm{Cx} 40 \mathrm{CT}$ revealed that the inhibitory effect of $\mathrm{Cx} 40$ on I $\kappa \mathrm{B} \alpha$ was not restricted to ECs and was independent of functional gap junction channels. Further studies should aim to identify the binding site of IкB $\alpha$ like in the $\mathrm{Cx} 40 \mathrm{CT}$ as this may represent a basis for the development of novel pharmacophores inhibiting proinflammatory $\mathrm{NF} \kappa \mathrm{B}$ signaling in multiple cell types and diseases.

In summary, our results show that $\mathrm{Cx} 40 \mathrm{CT}$ reduces endothelial activation by impairing $\mathrm{NF \kappa B}$ activation. Thus, Cx40 might confer athero-protection in the arterial endothelium by controlling inflammatory responses. As $\mathrm{Cx} 40$ is reduced by OSS, this mechanism may contribute to the increased atherosclerotic plaque formation at predilection sites where OSS is predominant, such as arterial bifurcations.

\section{MATERIALS AND METHODS}

\section{Animals}

Animal experimentation conformed to the Guide for the Care and Use of Laboratory Animals published by the US National Institutes of Health and was approved by Swiss cantonal veterinary authorities. The generation of heterozygous mice in which eGFP expression is controlled by the $C x 40$ promoter $\left(C x 40^{e G F P /+}\right.$ mice $)$ has been described elsewhere in detail [32]. Atherosclerosis-susceptible mice with endothelial deletion of $\mathrm{Cx} 40$, i.e. Tie $2 \mathrm{Cre}^{T g} \mathrm{Cx} 40^{f /}$

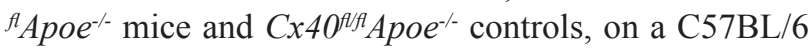
background, have been generated as previously described $[13,33]$. Genotypes of the different mice were verified by PCR using previously described protocols [13, 32, 33]. All mice were kept in conventional housing. 


\section{In vivo alteration of shear stress}

A shear stress-modifying cast was used to induce defined changes in shear stress, as previously described [ $[15$, 34]. In brief, mice were anesthetized with 5\% isoflurane inhalation for induction, followed by $2 \%$ isoflurane for maintenance of anesthesia. The anterior cervical triangle was accessed by a sagittal anterior neck incision. Both halves of the vascular cast were placed around the right common carotid artery and fixed with a suture. Post-operative analgesia was performed with i.p. Buprenorphinum $(0.05$ $\mathrm{mg} / \mathrm{kg}$ ) injections for 3 days. $C x 40^{e G F P /+}$ mice were fed a normal chow diet and were sacrificed 1 week after cast placement following general anesthesia with ketamine 100 $\mathrm{mg} / \mathrm{kg}$ and xylasine $10 \mathrm{mg} / \mathrm{kg}$ i.p. Carotids were retrieved, opened longitudinally, pinned in silicone dishes and were further processed for immunofluorescence. Immunosignal in the casted carotid regions were normalized to the signal in the undisturbed contralateral control carotid artery.

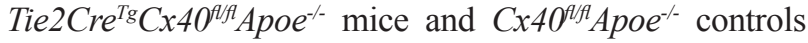
were fed a high-cholesterol diet for 6 weeks. After perfusion with $0.9 \% \mathrm{NaCl}$, casted vessels and contralateral undisturbed control vessels were excised and the cast was removed. Samples were embedded in OCT compound and snap frozen. Five $\mu \mathrm{m}$-thick serial cryosections were obtained from the 3 flow regions determined by the conical, progressively constrictive shape of the cast (upstream - LLSS, inside HLSS, downstream - OSS) and from the control vessel. Sections were stained with general histochemical methods such as Hematoxylin/Eosin, picrosirius red (for collagen) and Sudan IV (for lipids).

\section{Phage display}

We used phage display to identify potential ligates to the $\mathrm{C}$-terminal domain of $\mathrm{Cx} 40(\mathrm{Cx} 40 \mathrm{CT})$. The protocol was similar to that previously described $[30,31]$. Briefly, recombinant Cx40CT (amino acids 231-358) was used as bait. A well of a 24-well plate was coated with $15 \mu \mathrm{g}$ of recombinant $\mathrm{Cx} 40 \mathrm{CT}$. The well was subsequently treated with blocking buffer $\left(0.1 \mathrm{M} \mathrm{NaHCO}_{3}(\mathrm{pH} 8.6)\right.$, $5 \mathrm{mg} / \mathrm{mL} \mathrm{BSA}, 0.02 \% \mathrm{NaN}_{3}$ ) for 1 hour to prevent nonspecific binding. A phage library consisting of $2.7 \times 10^{9}$ different M13KE bacteriophage displaying a random 12mer peptide in their minor coat protein (Ph.D.-12 ${ }^{\mathrm{TM}}$ Phage display peptide library kit; New England BioLabs Inc.) was first pre-cleared in an uncoated well, and then presented to the bait protein. Low-affinity binders were first eluted using a $100 \mu \mathrm{g} / \mathrm{ml}$ solution of free Cx40CT in TBS. The well was overlaid with a culture of E. coli ER2738, which was then amplified for 4.5 hours. The amplified phage were precipitated with $\mathrm{PEG}-\mathrm{NaCl}$. The extracted phage were subsequently used for a new round of panning. After four rounds, the phage were grown on a lawn of E. coli ER2738 for plaque purification. A total of 118 plaques, each one representing a single clone, were amplified for 4.5 hours. Phage were precipitated with $\mathrm{PEG} / \mathrm{NaCl}$ and their
ssDNAs were extracted and sequenced. The sequences were analyzed using the ExPasy translate tool. Homology to human proteins was determined using the NCBI proteinprotein BLAST (Basic Local Alignment Search Tool).

\section{Motif analysis}

The significance of particular motifs in the retrieved phage display sequences was assessed by comparing their actual frequency to their theoretical occurrence based on the experimental ratio of each amino acid. If for example the frequency of $\mathrm{K}$ in the display sequences is $3.8 \%$, the frequency of $\mathrm{R}$ is $7.2 \%$ and the frequency of $\mathrm{P}$ is $11.4 \%$, then the probability of finding a $[\mathrm{K}, \mathrm{R}] \mathrm{XP}$ motif in a 12 mer would be $\mathrm{p}([\mathrm{K}, \mathrm{R}] \mathrm{XP})=10 \mathrm{x}(\mathrm{p}(\mathrm{K})+\mathrm{p}(\mathrm{R})) \times \mathrm{p}(\mathrm{P})$ $=12.4 \%$ even without a selection for this motif. These probabilities were then compared to the obtained data.

\section{Cross-linking experiments and proximity ligation assays}

For cross-linking, recombinant Cx $40 \mathrm{CT}(0.25 \mathrm{mM})$ and a peptide $(0.5 \mathrm{mM})$ were incubated for 1 hour at room temperature (RT) with $1 \mathrm{mM}$ of the cross-linker reagent $\mathrm{BS}^{3}$ at $\mathrm{pH} 7.45$. The reaction was subsequently blocked with $100 \mathrm{mM}$ ethanolamine for $10 \mathrm{~min}$. The samples were separated by SDS-PAGE (4-20\%) and stained with Coomassie-Blue.

Proximity ligation assays (PLA) were performed using the DUOLink ${ }^{\mathrm{TM}}$ kit (Olink) according to the manufacturer's protocol. In brief, rat carotid arteries were opened longitudinally, pinned out on silicone dishes, fixed with $100 \%$ methanol for $5 \mathrm{~min}$ at $-20^{\circ} \mathrm{C}$, permeabilized with $0.2 \%$ Triton $\mathrm{X}-100$ in PBS for 1 hour, charges neutralized with $0.5 \mathrm{M} \mathrm{NH}_{4} \mathrm{Cl}$ in $\mathrm{PBS}$ for $15 \mathrm{~min}$ and blocked in $2 \%$ bovine serum albumin (BSA) for $30 \mathrm{~min}$. Subsequently, primary antibodies against $\mathrm{Cx} 40$ (Cx40-A; Alpha-Diagnostics lot \#175455A8.6; 1/200) and IкB $\alpha$ (L35A5; Cell Signaling; 1/100) in blocking solution were applied overnight at $4^{\circ} \mathrm{C}$. Next, secondary PLA probes (PLUS and MINUS) in blocking solution were applied and proximity ligation was performed using the Duolink detection reagent RED kit according to the manufacturer's protocol. Cell-cell junctions were counterstained with Cx37 (Cx37A11-A; Alpha-Diagnostics, lot \#175859A5$\mathrm{L} ; 1 / 50$ ) diluted in $2 \%$ BSA and nuclei were stained with DAPI. Finally, the sections were mounted using Vectashield (Vector Laboratories) and analysed using a LSM510-Meta confocal microscope (Zeiss).

\section{Cell culture and transfection}

Different cell lines were used: a) a mouse endothelial cell line (bEnd.3) which endogenously expresses all three endothelial connexins [16], b) a communicationincompetent sub-clone of human HeLa cells (American Type Culture Collection) and c) the afore-mentioned HeLa 
cells stably transfected with murine Cx40 [35]. Cells were grown in DMEM (41966-029, Gibco) supplemented with $10 \%$ fetal bovine serum, $5000 \mathrm{U} / 1$ penicillin and $5 \mathrm{mg} / \mathrm{ml}$ streptomycin (Mediatech). The medium of the stably Cx40transfected HeLa cells was supplemented with $0.5 \mu \mathrm{g} / \mathrm{ml}$ puromycin (Sigma). bEnd.3 cells were grown on dishes or coverslips coated with $1.5 \%$ gelatin. For flow experiments, cells were counted and grown in gelatin-coated u-slides $\mathrm{VI}^{0.4}$ (Ibidi). Immunosignals in LLSS, HLSS and OSS were normalized to the signal in static conditions.

Silencing Cx40 in bEnd.3 cells using short interfering RNA (siRNA) was performed using SMARTpool ON-TARGETplus Gja5 siRNA (Dharmacon) specific for mouse $\mathrm{Cx} 40$ ( $\mathrm{mCx} 40)$. The ON-TARGETplus Non-targetting Pool (Dharmacon), which does not target known mouse sequences, was used as negative control. Transfections were performed under serum-free conditions, with $25 \mathrm{nM}$ siRNA and $2 \mathrm{mg} / \mathrm{l}$ DharmaFECT4. Efficient Cx40 silencing was determined by qPCR and immunofluorescence.

Transient transfections with pIRES2-eGFP containing cDNA coding for murine $\mathrm{Cx} 40$ or murine Cx40CT [36] were performed using Lipofectamine LTX\&PLUS ${ }^{\text {TM }}$ Reagent (Thermofisher) according to the manufacturer's instructions. Briefly, $1 \times 10^{6}$ communicationincompetent HeLa cells were grown for 24 hours in 6-well plates. For transfection, $2.5 \mu \mathrm{g}$ of plasmid, $2.5 \mu \mathrm{l}$ of PLUS Reagent and $12.5 \mu \mathrm{l}$ of Lipofectamine LTX were mixed in $300 \mu$ Opti-MEM Medium (Gibco) and incubated at RT for $5 \mathrm{~min}$. Then, the plasmid-Lipofectamine LTX complexes were added to each well supplemented with 1.7 $\mathrm{ml} \mathrm{DMEM}$ and incubated for 24 hours at $37^{\circ} \mathrm{C}$. Transfected cells were selected with $500 \mu \mathrm{g} / \mathrm{ml} \mathrm{G} 418$ (Gibco) added to the complete medium (changed every 2 days). Purity of the transfectants was followed every passage by FACS (BD Accuri C6). Experiments were performed when 70-80\% of the cells were eGFP positive.

\section{Quantitative PCR}

Total RNA from bEnd.3 cells was obtained using the NucleoSpin kit (Macherey-Naegel). Reverse transcription was performed using the Quantitect Reverse Transcription kit (Qiagen) and quantitative PCR was performed with the ABI Prism StepOnePlus Sequence Detection System (Applied Biosystems) using the TaqMan Fast Universal master mix (Applied Biosystem). Mouse Cx40 (Mm00433619_S1; Thermofisher Scientific) and GAPDH (Mm99999915_G1; Thermofisher Scientific) were used as Taqman probes. $\mathrm{Cx} 40$ expression was normalized to GAPDH expression.

\section{Immunofluorescence microscopy}

$\mathrm{Cx} 40$ and $\mathrm{NF \kappa B}$ immunofluorescent staining on carotid arteries, HeLa cells and bEnd.3 cells was performed as previously described [16]. In brief, longitudinally opened arteries or cells cultured on coverslips were fixed in $100 \%$ methanol at $-20^{\circ} \mathrm{C}$ for 5 min. After fixation all samples were permeabilized with $0.2 \%$ TritonX-100, charges neutralized with $0.5 \mathrm{M} \mathrm{NH}_{4} \mathrm{Cl}$ in PBS for 15 min and blocked in 2\% BSA. Subsequently, primary antibodies against $\mathrm{Cx} 40$ (Cx40-A; AlphaDiagnostics lot \#175455A8.6; 1/200), Cx37 (Cx37A11-A;

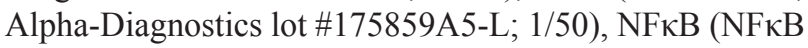
p65 (A) sc-109; Santa Cruz; 1/100) or Phospho-NFкB (Phospho-NFкB (S536)(93H1); Cell Signaling; 1/100) in blocking solution were applied overnight at $4{ }^{\circ} \mathrm{C}$. An Alexa Fluor 488 fluorochrome-conjugated goat anti-rabbit antibody (Life Technologies A11034; 1/5000) was used for signal detection. Cytoplasm and nucleic acids were counterstained with $0.003 \%$ Evans Blue (Sigma) and $1 / 20000$ DAPI (Invitrogen), respectively. For eGFP signal detection, arteries were fixed with 4\% PFA for $20 \mathrm{~min}$ at RT and processed for microscopy. Samples were mounted with Vectashield (Vector Laboratories) and analyzed with a confocal microscope (LSM510-Meta, Zeiss) using LSM AIM software, or an epifluorescent microscope (Axioskop-2, Zeiss) equipped with an AxioCam color CCD camera using Zeiss Axiovision 4.6 software. Quantification of Cx40 immunosignal was performed using ImageJ software.

\section{Western blot}

Cell cultures were rinsed with $\mathrm{PBS}, \mathrm{pH}=7.4$, and lysed in RIPA buffer as previously described [15]. After protein concentration quantification with a Micro BCA protein assay kit (Thermo Scientific), an equal quantity of protein was separated by SDS-PAGE and transferred to PVDF-membrane (Immobilon Millipore). After 2 hours blocking with 5\% milk and 1\% Tween in PBS, the membrane was exposed to primary antibodies (in blocking solution) detecting $\mathrm{Cx} 40$ (Cx40-A; Alpha-Diagnostics lot \#175455A8.6; 1/500), NFкB (NFkB p65 (A) sc-109; Santa Cruz; 1/1000), P-NFkB (Phospho-NFkB (S536)

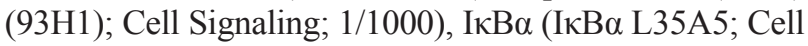

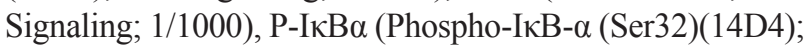
Cell Signaling; 1/1000) and GAPDH (Millipore MAB374; lot $\# 2388833 ; 1 / 30000)$ as loading control. Revelation was performed by incubating the membrane for 1 hour at RT with secondary horseradish peroxidase-conjugated antibodies (Jackson Immunoresearch; 1/5000) and followed by ECL detection (Millipore) using the Fuji LAS3000 (Fujifilm) and ImageQuant LAS 4000 software. Band intensities were thereafter quantified using ImageJ software.

\section{Dye coupling}

Dye transfer experiments on HeLa cells were performed as previously described [37]. In short, HeLa cells were cultured in $35-\mathrm{mm}$ dishes until confluence. Microelectrodes were pulled from borosilicate glass capillaries (WPI) using a pc-10 electrode puller 
(Narishige). The electrode was backfilled with 4\% Lucifer Yellow (Invitrogen) dissolved in $150 \mathrm{mM} \mathrm{LiCl}$ buffered to $\mathrm{pH}$ 7.2. Subsequently, the electrode was introduced into one HeLa cell and the dye was allowed to diffuse for $3 \mathrm{~min}$ or for $5 \mathrm{~min}$ in a separate set of experiments. Fluorescent cells were immediately counted using an inverted TMD300 microscope (Nikon) equipped with a 40x phase 3 dark medium objective with numerical aperture of 0.7 (Zeiss) and a Lucifer Yellow filter (Zeiss).

\section{Statistical analysis}

Results are presented as mean \pm SEM. Unpaired Student's t-tests or one-way ANOVAs were used to compare differences between groups. Differences with a $P<0.05$ were considered statistically significant; $*, \mathrm{P}<$ $0.05 ; * *, \mathrm{P}<0.01 ; * * *, \mathrm{P}<0.001 ; * * * *, \mathrm{P}<0.0001$.

\section{ACKNOWLEDGMENTS}

We thank Angela Baertschi-Roatti, Bernard Foglia, Esther Sutter, Wanda Coombs, Li Gao and Mingliang Zhang for excellent technical assistance.

\section{CONFLICTS OF INTEREST}

The authors declare no competing financial interests.

\section{GRANT SUPPORT}

This work was supported by grants from the Swiss National Science Foundation (310030_143343 and 310030_162579 to BRK), a joint grant from the SNF, the Swiss Academy of Medical Sciences and the Velux Foundation (323630-123735 to AP), Fondation Carlos et Elsie de Reuter (to BRK) and a BHF grant (RG/11/13/29055) and BHF-Centre of Excellence to RK.

\section{REFERENCES}

1. WHO. The top 10 causes of death. http://www.who.int/ mediacentre/factsheets/fs310/en/.2014.

2. Yla-Herttuala S, Bentzon JF, Daemen M, Falk E, GarciaGarcia HM, Herrmann J, Hoefer I, Jauhiainen S, Jukema JW, Krams R, Kwak BR, Marx N, Naruszewicz M, et al. Stabilization of atherosclerotic plaques: an update. European heart journal. 2013; 34:3251-3258.

3. Hansson GK, Libby P, Tabas I. Inflammation and plaque vulnerability. Journal of internal medicine. 2015; 278:483-493.

4. Davies PF. Hemodynamic shear stress and the endothelium in cardiovascular pathophysiology. Nature clinical practice Cardiovascular medicine. 2009; 6:16-26.

5. Kwak BR, Back M, Bochaton-Piallat ML, Caligiuri G, Daemen MJ, Davies PF, Hoefer IE, Holvoet P, Jo H, Krams
R, Lehoux S, Monaco C, Steffens S, et al. Biomechanical factors in atherosclerosis: mechanisms and clinical implications. European heart journal. 2014; 35:3013-3020, 3020a-3020d.

6. Morbiducci U, Kok AM, Kwak BR, Stone PH, Steinman DA, Wentzel JJ. Atherosclerosis at arterial bifurcations: evidence for the role of haemodynamics and geometry. Thrombosis and haemostasis. 2016; 115:484-492.

7. Hopkins PN. Molecular biology of atherosclerosis. Physiological reviews. 2013; 93:1317-1542.

8. Hajra L, Evans AI, Chen M, Hyduk SJ, Collins T, Cybulsky MI. The NF-kappa B signal transduction pathway in aortic endothelial cells is primed for activation in regions predisposed to atherosclerotic lesion formation. Proceedings of the National Academy of Sciences of the United States of America. 2000; 97:9052-9057.

9. Passerini AG, Polacek DC, Shi C, Francesco NM, Manduchi E, Grant GR, Pritchard WF, Powell S, Chang GY, Stoeckert CJ Jr, Davies PF. Coexisting proinflammatory and antioxidative endothelial transcription profiles in a disturbed flow region of the adult porcine aorta. Proceedings of the National Academy of Sciences of the United States of America. 2004; 101:2482-2487.

10. Davies PF, Civelek M, Fang Y, Fleming I. The atherosusceptible endothelium: endothelial phenotypes in complex haemodynamic shear stress regions in vivo. Cardiovascular research. 2013; 99:315-327.

11. Cuhlmann S, Van der Heiden K, Saliba D, Tremoleda JL, Khalil M, Zakkar M, Chaudhury H, Luong le A, Mason JC, Udalova I, Gsell W, Jones H, Haskard DO, et al. Disturbed blood flow induces RelA expression via c-Jun N-terminal kinase 1: a novel mode of NF-kappaB regulation that promotes arterial inflammation. Circulation research. 2011; 108:950-959.

12. Brisset AC, Isakson BE, Kwak BR. Connexins in vascular physiology and pathology. Antioxidants \& redox signaling. 2009; 11:267-282.

13. Chadjichristos CE, Scheckenbach KE, van Veen TA, Richani Sarieddine MZ, de Wit C, Yang Z, Roth I, Bacchetta M, Viswambharan H, Foglia B, Dudez T, van Kempen MJ, Coenjaerts FE, et al. Endothelial-specific deletion of connexin40 promotes atherosclerosis by increasing CD73-dependent leukocyte adhesion. Circulation. 2010; 121:123-131.

14. Cheng C, Tempel D, van Haperen R, van der Baan A, Grosveld F, Daemen MJ, Krams R, de Crom R. Atherosclerotic lesion size and vulnerability are determined by patterns of fluid shear stress. Circulation. 2006; 113:2744-2753.

15. Pfenniger A, Wong C, Sutter E, Cuhlmann S, DunoyerGeindre S, Mach F, Horrevoets AJ, Evans PC, Krams R, Kwak BR. Shear stress modulates the expression of the atheroprotective protein $\mathrm{Cx} 37$ in endothelial cells. Journal of molecular and cellular cardiology. 2012; 53:299-309. 
16. Kwak BR, Pepper MS, Gros DB, Meda P. Inhibition of endothelial wound repair by dominant negative connexin inhibitors. Molecular biology of the cell. 2001; 12:831-845.

17. Laird DW. The gap junction proteome and its relationship to disease. Trends in cell biology. 2010; 20:92-101.

18. Agullo-Pascual E, Cerrone M, Delmar M. Arrhythmogenic cardiomyopathy and Brugada syndrome: diseases of the connexome. FEBS letters. 2014; 588:1322-1330.

19. Soderberg O, Gullberg M, Jarvius M, Ridderstrale K, Leuchowius KJ, Jarvius J, Wester K, Hydbring P, Bahram F, Larsson LG, Landegren U. Direct observation of individual endogenous protein complexes in situ by proximity ligation. Nat Methods. 2006; 3:995-1000.

20. Pfenniger A, Meens MJ, Pedrigi RM, Foglia B, Sutter E, Pelli G, Rochemont V, Petrova TV, Krams R, Kwak BR. Shear stress-induced atherosclerotic plaque composition in $\mathrm{ApoE}(-/-)$ mice is modulated by connexin 37 . Atherosclerosis. 2015; 243:1-10.

21. Sun SC, Ganchi PA, Ballard DW, Greene WC. NF-kappa B controls expression of inhibitor I kappa B alpha: evidence for an inducible autoregulatory pathway. Science. 1993; 259:1912-1915.

22. Wei N, Serino G, Deng XW. The COP9 signalosome: more than a protease. Trends in biochemical sciences. 2008; 33:592-600.

23. Schweitzer K, Bozko PM, Dubiel W, Naumann M. CSN controls NF-kappaB by deubiquitinylation of IkappaBalpha. The EMBO journal. 2007; 26:1532-1541.

24. Kameritsch P, Pogoda K, Ritter A, Munzing S, Pohl U. Gap junctional communication controls the overall endothelial calcium response to vasoactive agonists. Cardiovascular research. 2012; 93:508-515.

25. Kwak BR, Veillard N, Pelli G, Mulhaupt F, James RW, Chanson M, Mach F. Reduced connexin43 expression inhibits atherosclerotic lesion formation in low-density lipoprotein receptor-deficient mice. Circulation. 2003; 107:1033-1039.

26. Morel S, Chanson M, Nguyen TD, Glass AM, Richani Sarieddine MZ, Meens MJ, Burnier L, Kwak BR, Taffet SM. Titration of the gap junction protein Connexin43 reduces atherogenesis. Thrombosis and haemostasis. 2014; 112:390-401.

27. Wong CW, Christen T, Roth I, Chadjichristos CE, Derouette JP, Foglia BF, Chanson M, Goodenough DA, Kwak BR. Connexin 37 protects against atherosclerosis by regulating monocyte adhesion. Nat Med. 2006; 12:950-954.

28. Gabriels JE, Paul DL. Connexin43 is highly localized to sites of disturbed flow in rat aortic endothelium but connexin 37 and connexin40 are more uniformly distributed. Circulation research. 1998; 83:636-643.

29. Vorderwulbecke BJ, Maroski J, Fiedorowicz K, Da SilvaAzevedo L, Marki A, Pries AR, Zakrzewicz A. Regulation of endothelial connexin40 expression by shear stress. American journal of physiology Heart and circulatory physiology. 2012; 302:H143-152.

30. Shibayama J, Lewandowski R, Kieken F, Coombs W, Shah S, Sorgen PL, Taffet SM, Delmar M. Identification of a novel peptide that interferes with the chemical regulation of connexin43. Circulation research. 2006; 98:1365-1372.

31. Pfenniger A, Derouette JP, Verma V, Lin X, Foglia B, Coombs W, Roth I, Satta N, Dunoyer-Geindre S, Sorgen P, Taffet S, Kwak BR, Delmar M. Gap junction protein Cx37 interacts with endothelial nitric oxide synthase in endothelial cells. Arteriosclerosis, thrombosis, and vascular biology. 2010; 30:827-834.

32. Miquerol L, Meysen S, Mangoni M, Bois P, van Rijen HV, Abran P, Jongsma H, Nargeot J, Gros D. Architectural and functional asymmetry of the His-Purkinje system of the murine heart. Cardiovascular research. 2004; 63:77-86.

33. Morel S, Braunersreuther V, Chanson M, Bouis D, Rochemont V, Foglia B, Pelli G, Sutter E, Pinsky DJ, Mach F, Kwak BR. Endothelial Cx40 limits myocardial ischaemia/reperfusion injury in mice. Cardiovascular research. 2014; 102:329-337.

34. Cheng C, van Haperen R, de Waard M, van Damme LC, Tempel D, Hanemaaijer L, van Cappellen GW, Bos J, Slager CJ, Duncker DJ, van der Steen AF, de Crom R, Krams R. Shear stress affects the intracellular distribution of eNOS: direct demonstration by a novel in vivo technique. Blood. 2005; 106:3691-3698.

35. Elfgang C, Eckert R, Lichtenberg-Frate H, Butterweck A, Traub O, Klein RA, Hulser DF, Willecke K. Specific permeability and selective formation of gap junction channels in connexin-transfected HeLa cells. The Journal of cell biology. 1995; 129:805-817.

36. Anumonwo JM, Taffet SM, Gu H, Chanson M, Moreno AP, Delmar M. The carboxyl terminal domain regulates the unitary conductance and voltage dependence of connexin40 gap junction channels. Circulation research. 2001; 88:666-673.

37. Kwak BR, Hermans MM, De Jonge HR, Lohmann SM, Jongsma HJ, Chanson M. Differential regulation of distinct types of gap junction channels by similar phosphorylating conditions. Molecular biology of the cell. 1995; 6:1707-1719. 